UDK 342.7-053.2:614.4

Review article

\title{
IMPACT OF COVID CRISIS ON CHILD'S RIGHT TO EDUCATION
}

\author{
Barbara Preložnjak, PhD, Assistant Professor \\ Faculty of Law, University of Zagreb \\ Trg Republike Hrvatske 3, Croatia \\ barbara.preloznjak@pravo.hr
}

\begin{abstract}
The right to education is regulated by norms of many international and regional documents. It includes many rights and plays an important role in the "all-round development of man" and its scope: physical, emotional, ethical, aesthetic, intellectual, professional, civic and international. The right to education is not the exclusive right of children. It is first and foremost the right of children and is essential for children's development. Therefore, it is generally accepted that educational opportunities should be equal for children.

Unfortunately, the right to education has been severely curtailed in a short period of time due to the COVID -19 pandemic. According to UNESCO, 191 countries have temporarily closed national or local schools to contain the spread of COVID -19. This has resulted in school-age children being unable to receive basic education.

This situation is particularly difficult for children from dysfunctional or disadvantaged families. Some families do not have internet, computers or books. Some parents cannot help them with homework because of educational or language limitations. All these unequal educational opportunities limit schooling.

On the way to eliminate inequality in access to education and protect children from rights violations, the author will discuss whether Rawls' principle of fairness provides a good basis for the government to take action to eliminate unequal opportunities for education.
\end{abstract}

Keywords: equality of opportunity, children, right to education, COVID-19 pandemic

\section{INTRODUCTION}

Education is usually defined as "the acquisition of knowledge, skills, and a moral code that are indispensable prerequisites for the ability to eventually pursue a cho- 
sen profession and thereby earn a living." Thus, it can be understood that education is considered essential for human beings to face the challenges of daily life, as it enables human beings to satisfy basic needs such as health and dignity and to develop their own personality with full freedom. ${ }^{2}$

Equal access to education is very important for children, because children who do not have equal educational opportunities are deprived of the possibility to succeed in education, in the labour market and in civic and social life. ${ }^{3}$ To achieve the goal of equal access to education, all children must have access to education, to universal and inclusive education, i.e. in terms of children's rights, access to education is the right of every child to receive education on the basis of equal opportunities.

Since March 2020, schools for more than 168 million children worldwide have been completely closed for almost a year due to the COVID -19 pandemic. ${ }^{4}$ In Europe, some 58 million school-age children who attended primary and secondary schools are deprived of the opportunity to learn regularly and privately with educational professionals. ${ }^{5}$ Thus, the pandemic has led to growing inequality in education. The inequality among children is due to the lack of internet access, the lack of a quiet place to study when all or most families are at home during the pandemic, the lack of reading materials which affects reading opportunities, and the lack of important sources of information, while the materially disadvantaged children lose an important source of their daily nutrition as schools are the main providers of their daily meals. ${ }^{6}$

According to the report on educational inequalities and physical school closures during Covid-19, the proportion of children who do not have internet access varies widely between and within countries. ${ }^{7}$ For example, children with parents

Beiter, K., D., The Protection of the Right to education The Protection of the Right to Education by International Law: Including a Systematic Analysis of Article 13 of the International Covenant on Economic, Social and Cultural Rights, Martinus Nijhoff, International Studies in Human Rights, Vol. 82, 2006, pp. 18-19.

2 Ibid., p. 18.; Pimentel, C., The Human Right to Education: Freedom and Empowerment, Multicultural Education, Vol. 13, No. 4, 2006, p. 5.

3 Weishart, J. E., Reconstituting the right to education, Alabama Law Review, Vol. 67, No. 4, 2016, p. 958.

4 [https://www.unicef.org/press-releases/schools-more-168-million-children-globally-have-been-completely-closed], Accessed 31 March 2021.

5 Blaskó, Z.; Schnepf, S., V., Educational inequalities and physical school closures during Covid-19, 2020, [https://ec.europa.eu/jrc/en/research/crosscutting-activities/fairness], Accessed 31 March 2021.

6 Ibid.

7 The report used data from the International Association for the Evaluation of Educational Achievement's 2016 Progress in International Reading Literacy Study (PIRLS) for the analyses. The following European countries were analysed: Austria, Belgium, Bulgaria, Czech Republic, Denmark, England, Finland, France, Georgia, Germany, Hungary, Ireland, Italy, Latvia, Lithuania, Malta, Netherlands, 
with lower levels of education are 5-11\% less likely to go online than children with parents with higher levels of education. ${ }^{8}$ Even if a child can use the internet and has at least one device at home, that doesn't necessarily mean they can use it for home schooling. ${ }^{9}$ In addition, the report found that in 21 European countries, $25 \%$ of young children do not have a quiet learning environment, compared to $9 \%$ in Denmark and $49 \%$ in Italy. ${ }^{10}$ In 21 European countries, at least $10 \%$ of children surveyed and as many as $24 \%$ of children from disadvantaged families did not receive enough reading material. ${ }^{11}$ Analysing all the data on inequality in education, more than a fifth of children lack at least two resources (i.e. a room of their own, reading opportunities, internet access, parental involvement), leading to unequal educational opportunities. ${ }^{12}$

As the crisis COVID -19 is still ongoing and it is still uncertain how long it will last and to what extent it will affect children's right to education, the question is whether we can eliminate unequal educational opportunities if access to education is challenged.

To answer this question, the author will analyse the meaning of the right to education in international and regional documents. In the next chapter, the author will analyse the components of most European constitutions and education laws that guarantee the right to education. Then, the concerns of unequal access to education in the case of the COVID -19 pandemic will be carried out and it will be discussed whether and to what extent the principle of equal opportunity is a good mechanism to address the inequality of educational opportunities.

\section{INTERNATIONAL AND REGIONAL LEGAL FRAMEWORK OF THE CHILD'S RIGHT TO EDUCATION}

At the international level, the right to education is regulated by United Nation (UN) documents, which express the right in terms of principles whose implementation and enforcement is largely left to individual states. ${ }^{13}$ The right to education, at international level, was first defined in the 1948 Universal Declaration

Northern Ireland, Norway, Poland, Portugal, Slovak Republic, Spain, Sweden. See [https://www.iea. nl/studies/iea/pirls/2016], Accessed 31 March 2021.; Ibid.

$8 \quad$ Ibid.

$9 \quad$ Ibid.

10 Ibid.

11 Ibid.

12 Ibid.

13 Right to Education, [https://www.right-to-education.org/page/international-law], Accessed 01 April 2021; [https://www.right-to-education.org/page/european-framework], Accessed 01 April 2021. 
of Human Rights (UDHR), where Article 26 clearly states that education is a universal right. ${ }^{14}$ The UDHR sets out the objectives of education in Article 26(2) by requiring that education "shall be directed to the full development of the human personality, the strengthening of respect for human rights and fundamental freedoms, the promotion of understanding, tolerance and friendship among all peoples, races and religious groups, and the encouragement of UN action for the maintenance of peace".

In 1960, the General Assembly of UN Educational, Scientific and Cultural Organisation (UNESCO) adopted the Convention against Discrimination in Education (CDE).${ }^{15}$ It is the first international instrument to set comprehensive international standards for public education in order to promote equality of opportunity and treatment for all in education. ${ }^{16}$ Three provisions guarantee equality in education: Article 1(1), which defines "discrimination" as denying education to a person or a group of people and allowing a person or a group of people to receive a lower education; Article 3, which states that the state is obliged to ensure that there is no discrimination in enrolment; Article 4, which states that the state is obliged to promote equality of opportunity and treatment in education, to ensure that all public education institutions have the same level of education, and to ensure that teachers are trained without discrimination. ${ }^{17}$

The objectives of education are prescribed in Article 5(1)(a), which states that education "shall promote the full development of the human personality and the strengthening of respect for human rights and fundamental freedoms; shall foster understanding, tolerance and friendship among all nations, races or religious groups; and shall promote the activities of the United Nations for the maintenance of peace." 18

The right to education was also enshrined in the International Covenant on Economic, Social and Cultural Rights (ICESCR) in 1966. ${ }^{19}$ Article 13 of the IC-

14 Article 26(1) states that "everyone has the right to education..." See: UN General Assembly, Universal Declaration of Human Rights, 10 December 1948, 217 A (III), [https://www.refworld.org/ docid/3ae6b3712c.html], Accessed 03 March 2021.

15 UN Educational, Scientific and Cultural Organisation (UNESCO), Convention Against Discrimination in Education, 14 December 1960, [https://www.refworld.org/docid/3ae6b3880.html], Accessed 04 March 2021.

16 Hodgson, D., The international human right to education and education concerning human rights, International Journal of Children's Rights, Vol. 4, No. 3, 1996, pp. 241-242.

17 See Article 1(1), Article (3), Article (4) CDE.

18 Article 5(1)(a) CDE.

19 See Articles 13 and 14 UN General Assembly, International Covenant on Economic, Social and Cultural Rights, 16 December 1966, United Nations, Treaty Series, vol. 993, p. 3, [https://www.refworld.org/ 
ESCR recognises education in general as a right and obliges states parties to realise the right to education. Article 13(1) of the ICESCR sets out the same educational objectives as Article 26(2) of the UDHR. ${ }^{20}$ Article 13(2) of the ICESCR sets out the obligation to make education accessible. ${ }^{21}$ This means that the state has the responsibility to ensure that all people have access to schools, teachers and educational materials, and to remove all barriers to enrolment so that all people can receive education. ${ }^{22}$ The state, as duty bearer, should provide free and compulsory primary education; secondary education should be made public and accessible by all appropriate means, in particular through the progressive introduction of free education, so that all people have an equal opportunity to obtain higher education. ${ }^{23}$ Article 13(2) embodies the social significance of the right to education and, together with Article 2(1) of the ICESCR, obliges states to strive "independently" for the full realisation of the right to education or "through international assistance and cooperation, in particular in the field of economic and technical cooperation". ${ }^{24}$ The right to education in the ICESCR may be subject to restrictions. Under Article 4, rights may be restricted if the law imposes restrictions; if they are in the nature of the right to education, they are restricted; and the purpose of the restrictions is to promote the general welfare of a democratic society. ${ }^{25}$

Many other international documents prepared by UN also recognise the right to education. These include the International Convention on the Elimination of All Forms of Racial Discrimination (UN General Assembly, 1966b); the Convention on the Elimination of All Forms of Discrimination against Women (UN General Assembly, 1979); and the Convention on the Rights of Persons with Disabilities (UN General Assembly, 2006). ${ }^{26}$

Recognising that children are a particularly vulnerable group in society, the United Nations has developed specifics for the application of human rights to children's education. Thus, the Declaration of the Rights of the Child (DRC) was adopted

docid/3ae6b36c0.html], Accessed 03 March 2021.

20 Compare Article 13(1) ICESCR and Article 26(2) UDHR.

21 The 160 countries that ratified the ICESCR reaffirmed this commitment, promising to make secondary and tertiary education accessible and progressively free for all (Article 13). Heymann, J., et. al., Constitutional rights to education and their relationship to national policy and school enrolment, International Journal of Educational Development, Vol. 39, 2014, p. 132.

22 Beiter, op. cit., note 1, p. 96.

23 Article 13(2) ICESCR.

24 Article 2 (1) ICESCR.

25 Article 4 ICESCR.

26 Heymann, J. et. al., op. cit., note 21, pp.132-133. 
in 1959 and the Convention on the Rights of the Child (CRC) in 1989. ${ }^{27}$ The CRC supplemented and expanded the provisions of the DRC. ${ }^{28}$ Like the UDHR, the DRC prescribes the right to education grants children the universal right to education, which is to be compulsory and free. ${ }^{29}$ States parties to CRC undertake to ensure free and compulsory primary education, to make secondary education "available and accessible to every child" through "measures such as the introduction of free education and the provision of financial assistance to those in need", and to make higher education "accessible to all according to their abilities". ${ }^{30}$ The right to education guaranteed by CRC must be achieved progressively and on the basis of equality of opportunity. ${ }^{31}$

In addition to the educational attainment obligations set out in the ICESCR, Article 28(1) of CRC introduces two new elements not included in the ICESCR. For example, Article 28(1)(d) obliges the state to provide and make accessible educational and vocational information and guidance to all children, while Article 28(1)(e) obliges the state to take measures to promote regular school attendance and reduce early school leaving.

The state shall, within its jurisdiction, "respect and ensure the right to education for every child without discrimination of any kind, irrespective of the child's or his or her parent's or legal guardian's race, colour, sex, language, religion, political or other opinion, national, ethnic or social origin, property, disability, birth or other status." 32 In other words, the state has a duty to ensure that no one is denied access to educational institutions in a discriminatory manner and should take measures to ensure equality in the exercise of the right to education. ${ }^{33}$

27 UN General Assembly, Declaration of the Rights of the Child, 20 November 1959, A/RES/1386(XIV), available at: [https://www.refworld.org/docid/3ae6b38e3.html], Accessed 03 March 2021; UN General Assembly, Convention on the Rights of the Child, 20 November 1989, United Nations, Treaty Series, vol. 1577, p. 3, [https://www.refworld.org/docid/3ae6b38f0.html], Accessed 03 March 2021.; Beiter, op. cit., note 1, p. 114.

28 Ibid.

29 Principle 7 of the DRC assigns parents' primary responsibility for their children's education and qualifies this responsibility by introducing "the best interest of the child" as the "guiding principle." Compare 26(1) i (3) UDHR and Principle 7 DRC.

30 The Committee on the Rights of the Child, established in 1991, monitors the implementation of CRC -protected rights, including the right to education. Heymann, op. cit., note 21, pp.132-133.; Article 28 CRC.

31 Ibid., Parks, A., Children and International Human Rights Law: The Right of the Child to be Heard, Routledge, 2013, p. 123.

32 Article 2(1) CRC.

33 Beiter, op. cit., note 1, p. 122. 
Article 29 (1) of the CRC adds a "qualitative dimension" to the right to education by establishing the holistic development of the child's full potential (29 (1) (a)), the development of respect for human rights (29 (1) (b)), a strengthened sense of identity and belonging (29 (1) (c)), the child's socialization and interaction with others (29 (1) (d)) and with the environment (29 (1) (e)) as objectives of education. ${ }^{34}$

The right to education is also protected by legal documents adopted at regional level by taking into account regional customs, values, culture and practices. ${ }^{35} \mathrm{In}$ Europe, the right to education has been protected by documents that are mainly drawn up by the Council of Europe and the European Community/Union. In 1952, the right to education was recognized as a universal right in Protocol No. 1 of the European Convention for the Protection of Human Rights and Fundamental Freedoms (P-1 ECHR), which was adopted by the Council of Europe. ${ }^{36}$ Article 2 of the P-1 ECHR protects the right to education as freedom of access to existing educational institutions and the right to equal access and use of educational institutions. ${ }^{37}$

The educational rights are also protected by European Social Charter (ESC) adopted by the Council of Europe which in its 1996 revisions of the article 17(2) requires that children and young people receive free education at primary and secondary

34 UN Committee on the Rights of the Child (CRC), General comment No. 1 (2001), Article 29 (1), The aims of education, 17 April 2001, CRC/GC/2001/1, paragraph 2., p. 2., [https:/www.refworld.org/ docid/4538834d2.html], Accessed 05 March 2021.

35 Regional legal instruments have been prepared in the European, American, African and certain other regional contexts. Beiter, op. cit., note 1, p. 155.

36 Council of Europe, Protocol 1 to the European Convention for the Protection of Human Rights and Fundamental Freedoms, 20 March 1952, ETS 9, available at: [https://www.refworld.org/docid/3ae6b38317. html], Accessed 28 April 2021.

37 The European Court of Human Rights has interpreted Article 2 of P-1 ECHR broadly in a number of decisions: Case Relating to Certain Aspects of the Laws on the Use of Languages in Education in Belgium, European Commission of Human Rights v Belgium, Merits, App No 1474/62, App No 1677/62, App No 1691/62, App No 1769/63, App No 1994/63, App No 2126/64, (1979-80) 1 EHRR 252, IHRL 6 (ECHR 1968), 23rd July 1968., p. 28, para 3-5.; Golder v United Kingdom, Judgment, Merits and Just Satisfaction, App No 4451/70, A/18, [1975] ECHR 1, (1979) 1 EHRR 524, IHRL 9 (ECHR 1975), 21st February 1975, p. 32, para. 5; Şahin v Turkey, Admissibility and Merits, App No 44774/98, ECHR 2005-XI, [2005] ECHR 819, (2007) 44 EHRR 5, (2006) 45 ILM 436, [2006] ELR 73, 19 BHRC 590, IHRL 3279 (ECHR 2005), 10th November 2005, para. 134138; Folgerø and ors v Norway, Merits and just satisfaction, App no 15472/02, (2008) 46 EHRR 47, IHRL 3235 (ECHR 2007), 29th June 2007, para. 83; Campbell and Cosans v United Kingdom, Merits, App No 7511/76, A/48, [1982] ECHR 1, (1982) 4 EHRR 293, IHRL 33 (ECHR 1982), 25th February 1982, para. 39-41; Tarantino and ors v Italy, Merits and just satisfaction, App nos 25851/09, IHRL 3986 (ECHR 2013), 29284/09, 64090/09, [2013] ECHR 255, 9th September 2013, para 50-51; Oršuš and ors v Croatia, Merits and just satisfaction, App no 15766/03, IHRL 3716 (ECHR 2010), 16th March 2010, para 111, 144-147. 
level, as well as encouragement to attend school regularly". ${ }^{38}$ Article 7 of ESC on child labor states that persons still in compulsory education shall not be employed as this would deprive them of the full benefits of education. The right to education is also guaranteed in Article 10, which guarantees the right to vocational training, and in Article 15, which regulates the right to education of persons with disabilities.

Further, articles 14 and 15 of the European Convention on Legal Status of Migrant Workers 1977 also protect the educational rights of migrant workers and their families. ${ }^{39}$ Articles 12 to 14 of the Framework Convention for the Protection of National Minorities 1995 are generally dedicated to the educational rights of minorities, while Article 8 of the European Charter for Regional or Minority Languages 1992 is dedicated to the use of minority languages in education. ${ }^{40}$

The Council of Europe regularly issues recommendations on education, such as the 2012 Recommendation on Ensuring Quality Education, the 2000 Recommendation on the Education of Roma/Gypsy Children in Europe, the 2009 Recommendation on the Education of Roma and Travellers in Europe, and the 2010 Recommendation on Public Responsibility for Higher Education and Research. ${ }^{41}$

Beside the Council of Europe documents, several European Union (EU) documents are relevant to the regulation of the right to education. For example, Articles 149 and 150 of the 1957 Treaty Establishing the European Community confer powers on European Community in the field of education and vocational train-

38 The European Social Charter (ECSR was created in 1961 to protect fundamental social standards and recognize a wide range of economic, social and cultural rights, including the right to education. It was revised on 3 May 1996 to expand the rights articulated in the original Charter. See Council of Europe, European Social Charter (Revised), 3 May 1996, ETS 163, [https://www.refworld.org/docid/3ae6b3678.html], Accessed 05 March 2021.

39 Council of Europe, European Convention on the Legal Status of Migrant Workers, 24 November 1977, ETS 93, [https://www.refworld.org/docid/3ae6b388c.html], Accessed 19 March 2021.

40 Council of Europe, Framework Convention for the Protection of National Minorities, 1 February 1995, ETS 157, [https://www.refworld.org/docid/3ae6b36210.html], Accessed 07 April 2021.; Council of Europe, European Charter for Regional or Minority Languages, 4 November 1992, ETS 148, [https://www.refworld.org/docid/3de78bc34.html], Accessed 07 April 2021.

41 Council of Europe: Recommendation CM/Rec(2012)13 of the Committee of Ministers to member States on ensuring quality education, 12 December 2012, Council of Europe: Committee of Ministers, Recommendation No. R (2000) 4 of the Committee of Ministers to member states on the education of Roma/Gypsy children in Europe, 3 February 2000, R (2000) 4, [https://www.refworld. org/docid/469e04c02.html], Accessed 08 April 2021, Council of Europe: Recommendation CM/ $\operatorname{Rec}(2009) 4$ of the Committee of Ministers to member states on the education of Roma and Travellers in Europe, 17 June 2009, Council of Europe: Committee of Ministers, Recommendation CM/ $\operatorname{Rec}(2012) 7$ of the Committee of Ministers to member States on the responsibility of public authorities for academic freedom and institutional autonomy, 20 June 2012, [https://www.refworld.org/ docid/50697ed62.html], Accessed 08 April 2021, European Framework, [https://www.right-to-education.org/page/european-framework], Accessed 19 March 2021. 
ing; Articles 7 (2) and (3) and 12 of Regulation 1612/68 and Directive 77/486 regulate the education of migrant workers and their children. ${ }^{42}$ In addition, Principle 1 of the 1984 European Community Resolution on Freedom of Education recognises the right of the child to education and the right of parents to determine the type of education for their children; Principle 2 states that the right to education is to be enjoyed without discrimination of any kind; and Principle 5 defines the purpose of education. ${ }^{43}$

Article 16 (1) and (2) of the 1989 Declaration of Fundamental Rights and Freedoms generally protects the right to education by stating that everyone has the right to education, to vocational training commensurate with his or her abilities, and to freedom of education. ${ }^{44}$

Article 14 of the 2000 Charter of Fundamental Rights of the European Union (Charter) also protects the right to equal access to education and vocational training, the right to compulsory education and the freedom to establish educational institutions while article 32 prohibits child labour and states that the minimum age for employment shall not be less than the age at which compulsory education is completed. ${ }^{45}$

\section{BASIC COMPONENTS OF THE RIGHT TO EDUCATION}

The international and regional documents entitle children, as holders of the right to education, to specific legal positions, the content of which has a complex internal structure ordered by the arrangement of the four basic components of rights - claim, privilege, power and immunity. ${ }^{46}$

Children have a claim-right which entitle them to the state, and it denotes educational adequacy. ${ }^{47}$ In other words, it denotes equal access to adequate educational

42 Treaty establishing the European Community (Consolidated version 2002) OJ C 325, 24.12.2002, p. 33-184; Regulation (EEC) No 1612/68 of the Council of 15 October 1968 on freedom of movement for workers within the Community (OJ L 257, 19.10.1968, pp. 2-12); Council Directive 77/486/ EEC of 25 July 1977 on the education of the children of migrant workers (OJ L 199, 6.8.1977, pp. 32-33).

43 Resolution on Freedom of Education in the European Community (OJ C 104, 16.4.1984, p. 69.).

44 Resolution adopting the Declaration of Fundamental Rights and Freedoms (A2-3/89, OJ C 120 of 16.05.1989, pp. 51-57.).

45 Charter of Fundamental Rights of the European Union (OJ C 326, 26.10.2012, p. 391-407).

46 The four components of rights are called "the Hohfeld incidents" after Wesley Hohfeld, an American legal theorist who discovered them. See Hohfeld, W., Fundamental Legal Conceptions, New Haven: Yale University Press, 1919.

47 According to adequacy theories, a fair educational opportunity requires only that students receive enough education to function as equal citizens. Burroughs, N. A., Rawls, republicanism, and the ade- 
resources and services. ${ }^{48}$ To achieve educational adequacy, the state should distribute educational resources equitably and state institutions should be designed to promote goals that are as equal as possible for all concerned. ${ }^{49}$ It means bringing children to a certain level of education, which should not be too low, because every child with potential should receive an adequate education. ${ }^{50}$ In order to define the adequacy threshold, the state must determine the right level of education by taking into account the educational goals that are usually associated with the idea that children can be able to be equal citizens after receiving the level of education. ${ }^{51}$ In general, basic education is accessible to all and consists of primary education (the first level of basic education) and lower secondary education (the second level of basic education). ${ }^{52}$

Children's claim-right corresponds to a duty imposed on the state to provide children with a basic education so that they can make proper use of a variety of basic goods, including their rights and freedoms. ${ }^{53}$ This means that the state has a duty to enact legal norms that promote basic education and ensure that children

quacy-equity debate, Theory and Research in Education, Vol. 14, Issue 2, 2016, p. 1.; Menéndez, F. S., Educational adequacy and educational equality: a merging proposal, Critical Review of International Social and Political Philosophy, Vol. 22, Issue 1, 2019, p. 2.

Equality in education could be defined as equality in educational resources, quality, opportunities, or outcomes. Giesinger, J., Educational justice: equality versus adequacy, in: Peters, Michael A.(ed.), Encyclopedia of educational philosophy and theory, Cham, Switzerland: Springer Singapore, 2018, pp. 1-5.

48 Weishart, op. cit., note 3, p. 922.

49 Giesinger, op. cit., note 47, p. 28.

50 Above a certain threshold, unequal educational opportunities are permitted. See: Burroughs, op. cit., note 47 , p. 5.

51 Giesinger, op. cit., note 47, p. 6.; Burroughs, op. cit., note 46, p. 9.

52 Ibid., p. 7., Satz, D., Equality, Adequacy, and Education for Citizenship, Symphosium on Education and Equality, Ethics, Vol. 117, No. 14, 2007, pp. 623-648.; [http://uis.unesco.org/en/glossary-term/ basic-education], Accessed 22 March 2021.

53 Podschwadek, F., Rawlsian liberalism and public education, PhD thesis, University of Glasgow, 2018, p. 21, 146.; A small number of constitutions (e.g. Croatia, Germany, Ireland, Italy, Liechtenstein, Luxembourg and the Netherlands) within the 43 Council of Europe states contain provisions on education that focus entirely on the rights and duties of parents and the state, without explicit reference to an individual right of the child to receive an education. Report on the Protection of Children's Rights, Council of Europe, adopted by the Venice Commission at its 98th Plenary Session, Venice, 21-22 March 2014, p. 19, [https://rm.coe.int/168062cf94], Accessed 01 April 2021.

${ }^{A}$ rticle 63(1) The Constitution of the Republic of Croatia Official Gazette No. 56/90, 135/97, 08/98, 113/00, 124/00, 28/01, 41/01, 55/01, 76/10, 85/10, 05/14; CHR states that "parents have a duty to bring up, support and educate their children." Article 63(2) states that "parents are responsible for ensuring the right of their children to the full and harmonious development of their personalities." Article 63(3) requires the State to provide "special care for parentless minors and parentally neglected children," and Article 63(3) provides that "physically and mentally handicapped and socially neglected children have the right to special care, education and welfare." It is stated in Article 64 that "everyone shall have the duty to protect children." 
grow up to be autonomous individuals capable of contributing to a democratic society. ${ }^{54}$ Moreover, the state has the second-order power to create, abrogate or cancel an claim-right to education, as the legislature has complete control over children's education by virtue of international and regional documents. ${ }^{55}$ On the other hand, the state has the privilege of exercising said power through the legislature and cannot be prevented from exercising it if it chooses to enact laws that "establish and maintain" schools that provide basic education or "establish detailed requirements for the provision of educational services." 56

Comparative studies have shown that states parties to international and regional documents fulfil their duty to ensure basic education by guaranteeing it through their constitutions and laws. However, the conception of basic education varies, as not every state guarantees compulsory education. ${ }^{57}$ For example, $68 \%$ of 1960 s constitution's guarantee a right to compulsory primary education, while $67 \%$ of 1970 s constitutions, $74 \%$ of 1980 s constitutions, $95 \%$ of 1990 s constitutions, and $97 \%$ of 2000s constitutions do so. ${ }^{58}$ Some states impose compulsory primary education, while others impose compulsory primary and secondary education. The percentage of constitutions that guaranteed compulsory primary education increased significantly from $27 \%$ in the 1960 s to $66 \%$ after 2000 , but most constitutions enacted between 1960 and 2011 do not mandate secondary or tertiary education. ${ }^{59}$

The majority (52\%) of constitutions adopted between 1960 and 2011 mentioned a general right to education without specifying the levels of obligation. ${ }^{60}$ Some

54 Not only does the state have a duty to promote basic education, but it should also refrain from actions that jeopardize a child's right to education by limiting his or her access to it. Weishart, op. cit., note 3 , p. 936, Podschwadek, op. cit., note 53, p. 105.

55 Weishart, op. cit., note 3, p. 927. The child's best interests must be the primary consideration in all actions involving the child. See Article 3. CRC; Heymann, op. cit., note 20, p. 138.; Burroughs, op. cit., note 45 .

56 Weishart, op. cit., note 3, p. 930, 936; The right to free primary education is guaranteed in the constitutions of almost all EU countries, and the state is responsible for providing it. The constitutions of Germany, Ireland, Austria and the Netherlands are notable exceptions to the explicit guarantee of free primary education. [https://www.worldpolicycenter.org/policies/does-the-constitution-explicitly-guarantee-free-education/does-the-constitution-explicitly-guarantee-citizens-right-to-free-primary-education], Accessed 22 March 2021.

57 Charges for education may mean that some parents are unable to educate all their children. Consequently, if education is not free, it cannot be made compulsory. Wilson, D., Gender equality in education: Human right perspective, p. 11., [https://www.ohchr.org/Documents/HRBodies/CEDAW/ WomensRightEducation/DuncanWilson.pdf], Accessed 01 April 2021.

58 Constitutions adopted after 1990, primarily in low- and middle-income countries, were more likely to protect education rights. Heymann, op. cit., note 21, pp. 131, 139.

59 One additional constitution, enacted in the 1990s, protected only the poor's right to free primary education. Heymann, op. cit., note 21, p. 136.

$60 \quad$ Ibid. 
$81 \%$ of constitutions guaranteed universal primary education and $53 \%$ made it free, while a minority provided for secondary education (37\%) and higher education $(35 \%)$ or explicitly protected certain groups. ${ }^{61}$ Today, within the EU, the constitutions of all countries guarantee compulsory and free primary education. ${ }^{62}$ In Croatia, constitutional provisions guarantee that everyone has the right to free compulsory primary education under equal conditions and according to their abilities. ${ }^{63}$ Secondary and higher education are accessible to all on equal terms and according to their abilities. ${ }^{64}$ Although secondary education is not compulsory in Croatia, almost all children attend general or vocational higher education after completing primary school. ${ }^{65}$ Completion of secondary education enables everyone to acquire knowledge and skills to work and/or further their education under equal conditions and according to individual abilities. ${ }^{66}$

International and regional documents, by guaranteeing the right to education, have given children an immunity that entails equality of educational opportunity. ${ }^{67}$ This immunity prevents the state from enacting laws that promote an unequal distribution of educational opportunities, and it prevents the state from depriving a child of his or her entitlement (claim-right) to an adequate education. ${ }^{68} \mathrm{It}$ also protects children from the harms of educational disadvantage by working to eliminate background disadvantages and giving children of equal ability and motivation equal opportunities to succeed in school. ${ }^{69}$

About $6 \%$ of states include norms in their constitutions aimed at preventing gender inequality in education, $5 \%$ include positive provisions to promote equality in education for ethnic minorities, $2 \%$ for religious minorities, $9 \%$ for the socioeconomically disadvantaged, $14 \%$ explicitly guarantee equality in education and $7 \%$ guarantee universal access to education while prohibiting widespread discrim-

\footnotetext{
61 Ibid.

62 Is education compulsory?, [https:/www.worldpolicycenter.org/policies/is-education-compulsory/ is-primary-education-compulsory], Accessed 01 April 2021; Is education tuition-free and compulsory?, [https://www.worldpolicycenter.org/policies/is-education-tuition-free-and-compulsory/is-primary-education-tuition-free-and-compulsory], Accessed 01 April 2021.

63 Article 66 CHR, Article 4 para 2, Article 12 para 1 Primary and Secondary School Education Act, Official Gazette, No. 87/08, 86/09, 92/10, 105/10, 90/11, 5/12, 16/12, 86/12, 126/12, 94/16, 154/14, 7/17; PSSEA.

64 Article 66 para 1 CHR.

65 Organisation of the Education System and of its Structure, [https://eacea.ec.europa.eu/national-policies/ eurydice/content/organisation-education-system-and-its-structure-14_en], Accessed 24. March 2021.

66 Article 11 para 4 PSSEA.

67 Weishart, op. cit., note 3, p. 922.

68 Weishart, op. cit., note 3, p. 935.

69 Burrough, op. cit, note 47, p. 2.
} 
ination on the basis of disability. ${ }^{70}$ The importance of standards protecting equal opportunities is recognized in the EU. Almost all EU countries have included the principle of educational equality in their constitutions and have enacted education laws that protect gender equality as an objective of equal treatment in education. ${ }^{71}$ The exceptions are Denmark and Italy, which have no specific reference in their constitutions or laws regulating gender equality in access to education. ${ }^{72}$ In Croatia, constitutional norms ensure that everyone has access to education under equal conditions. Gender equality is formulated as an objective of the education system because education for gender equality is an integral part of this system and lifelong learning involves the preparation of both genders for active and equal participation in all aspects of life. ${ }^{73}$

In addition, in most EU countries, children from minority or ethnic groups, as well as children with physical or mental disabilities or special educational needs, have the right to attend mainstream schools. ${ }^{74}$ They also have the right to expect to receive an education that will enable them to reach their full potential. ${ }^{75}$ Under the conditions and in accordance with a special law on education of national minorities, children of national minorities in Croatia may be educated in primary and secondary schools with instruction in the language and script they use. ${ }^{76}$ Refugees have the right to education protected by principles of equality in constitutions and education laws. ${ }^{77}$ In Bulgaria, Latvia and Sweden, for example, legal norms explicitly guarantee refugees the right to education under the same conditions as native children. ${ }^{78}$ While in Spain, legal norms ensure that every child, including refugees

\footnotetext{
$70 \quad$ Heymann, op. cit., note 21, pp. 135, 136.

71 Ibid..; More than 103 million children who are not in school 57\% are girls. Equal access to education, [https://europa.eu/capacity4dev/public-gender/wiki/equal-access-education], Accessed 01 April 2021.

72 Gender Differences in Educational Outcomes: Study on the Measures Taken and the Current Situation in Europe, Education, Audiovisual and Culture Executive Agency, 2010, p. 47., [http://lst-iiep.iiep-unesco.org/cgi-bin/wwwi32.exe/[in=epidoc1.in]/?t2000=028612/(100)], Accessed 23 March 2021.

73 Article 66 para 1 of the Constitution of the Republic of Croatia; Article 14 Gender Equality Act, Official Gazette, No. 82/08, 69/17.

74 Steering Committee for Equality Between Women and Men (CDEG), Strasbourg, 2011, p. 24. [https:// rm.coe.int/1680596131], Accessed 01 April 2021.

75 Ibid.

76 Minorities in Croatia, 2003, p. 25, [https://www.refworld.org/pdfid/469cbf8f0.pdf], Accessed 24 March 2021; Article 11 of the Constitutional Act on the Rights of National Minorities, Official Gazette, No. 155/02, 47/10, 80/10, 93/11; Act on the Use of Languages and Scripts of National Minorities in the Republic of Croatia, Official Gazette, No. 51/00.

77 Enforcing right to education of refugees: a policy protection, United Nations Educational, Scientific and Cultural, 2019, p. 26, [https://www.gcedclearinghouse.org/sites/default/files/resources/190208eng. pdf], Accessed 07 April 2021.

78 Ibid.
} 
and asylum seekers, has the right to education. ${ }^{79}$ Legal norms in Spain and France even regulate whether refugees can receive free and compulsory education. ${ }^{80} \mathrm{In}$ Croatia, children under the age of 18 seeking international protection have the right to primary and secondary education under Croatian law. ${ }^{81}$ They have the same access to primary and secondary education as Croatian citizens. ${ }^{82}$

As regards equal access to education for disabled children, not all EU constitutions contain explicit provisions. ${ }^{83}$ Only the constitutions of Portugal, Spain, Italy, Hungary, Slovenia and Austria guarantee the right to education for disabled children. ${ }^{84}$ In Croatia, legal provisions ensure that children with disabilities have equal access to primary education..$^{85}$ Children with learning difficulties are educated in mainstream schools with full or partial integration, with regular, individualized or special programs, depending on the type and degree of difficulty, or in exceptional cases in special educational institutions if the children need additional medical or social care. ${ }^{86}$

\section{RAWLS AND DISTRIBUTION OF EDUCATIONAL RIGHT IN COVID-19 PANDEMIC}

By regulating access to education, many European countries identify certain groups of children as vulnerable in their constitutions and education laws (e.g. children with disabilities, girls, minorities, refugees and the poor). ${ }^{87}$ Although these constitutional and legal norms guarantee adequacy and equality of opportunity in access to education, inequalities exist between children. Across the EU gender inequalities in education persist in terms of subject preferences and achievement, as well

\footnotetext{
79 Ibid.

80 Ibid.

81 Children who have begun to exercise their right to secondary education may continue to do so after the age of 18. Article 58 para 1 and 2 Law on International and Temporary Protection, Official Gazette, No. 70/15, 127/17; LITP.

82 Article 58 para 1 LITP.

83 Is education compulsory?, [https://www.worldpolicycenter.org/policies/is-education-compulsory/is-primary-education-compulsory], Accessed 24 March 2021.

84 Ibid.

85 Article 12 para 2 Act on Scientific Activity and Higher Education, Official Gazette, No. 123/03, 198/03, 105/04, 174/04, 02/07, 46/07, 45/09, 63/11, 94/13, 139/13, 101/14 and 60/15.

86 Organisation of the Education System and of its Structure, 2019, [https://eacea.ec.europa.eu/national-policies/eurydice/content/organisation-education-system-and-its-structure-14_en], Accessed 24 March 2021.

87 Global education monitoring report, 2020: Inclusion and education: all means all, Educational, Scientific and Cultural Organization, 2020, p. 67, [https://unesdoc.unesco.org/ark:/48223/pf0000373718], Accessed 01 April 2021.
} 
as qualitative aspects of the education and training experience and the proportion of children who drop out of school. ${ }^{88}$ For example, girls are less likely than boys to attend school and more likely than boys to drop out; performance in mathematics and science is gender neutral, but girls perform better than boys in reading, and so on. ${ }^{89}$ There are significant differences in early school leaving rates across most EU countries, with boys clearly at higher risk of dropping out of school before completing upper secondary education than girls. ${ }^{90}$ Countries with a high share of early school leavers, such as Spain, Malta, Portugal and Iceland, have more than $25 \%$ male and $20 \%$ female early school leavers, while countries with a low share of early school leavers, such as Czech Republic, Poland, Slovenia, Slovakia and Finland, have 5 to $10 \%$ male and 3 to $5 \%$ female early school leavers. Croatia has the lowest dropout rate in the EU, with $3.3 \%$ in 2018 and only $3 \%$ in $2019 .{ }^{91}$

The proportion of disabled children identified as having special educational needs varies widely across Europe, ranging from 1\% in Sweden to 21\% in Scotland (United Kingdom). ${ }^{92}$ According to an analysis of access to education for children with disabilities, they are less likely to be enrolled, stay in school, and receive support. ${ }^{33}$ In some European countries, such as Belgium and Germany, children with disabilities are educated in a special school or a separate class in a mainstream school. ${ }^{94}$ Compared to their peers in primary, lower secondary and upper secondary education, they are 1, 4 and 6 percentage points more likely to miss school. ${ }^{95}$

88 Lynch, K.; Feeley, M., Gender and Education (and Employment): Gendered imperatives and their implications for women and men lessons from research for policy makers, European Commission, 2003, p. 78, [http://www.nesse.fr/nesse/activities/reports/activities/reports/gender-report-pdf], Accessed 23 March 2021.

89 PISA 2015 Programme for International Student Assessment - Europe and Central Asia, World Bank Group Education, 2015, p. 7, [http://documents1.worldbank.org/curated/en/674021500448761959/ pdf/117585-PIS A-2015-ECA.pdf], Accessed 23 March 2021; Of the estimated 72 million children not in school, girls are the majority. Women and the right to education, United Nations Human Rights Office of the High Commissioner, 2010, [https://www.ohchr.org/Documents/Issues/Women/GenderAndEquality/Infonote_Women_and_the_right_to_education.pdf], Accessed 23 March 2021.

90 The exception regarding gender inequality in early leaving the schools is recorded in Belgium, Czech Republic, Slovakia, Sweden. Education, [https://eige.europa.eu/gender-mainstreaming/policy-areas/ education], Accessed 23 March 2021.

91 Early leavers from education and training, p. 77, [https://ec.europa.eu/eurostat/statistics-explained/index.php/Early_leavers_from_education_and_training], Accessed 23 March 2021.

92 Global education monitoring report, 2020, op. cit., note 87, p. 74.

93 World report on disability, World Health Organisation, 2011, p. 206, [https://www.right-to-education.org/sites/right-to-education.org/files/resource-attachments/WHO_World_Report_on_Disability_2011_En.pdf], Accessed 31 March 2021.

94 Ibid. p. 210.

95 Ibid. p. 210. 
In Croatia, $88.87 \%$ of all disabled pupils attended regular primary schools, while $11.13 \%$ attended special primary schools. ${ }^{96}$

There are some problems with equal access to education for ethnic minority children. For example, Roma children are the largest ethnic minority in Europe, living in poverty and facing prejudice, intolerance and discrimination. ${ }^{97}$ Their educational attainment is low and Roma children are far less likely to attend school than non-Roma children. ${ }^{98}$ Those who do attend school are often taught separately, as is the case in Czech Republic and Slovakia. ${ }^{99}$ In Croatia, Hungary and Romania, at least 5\% of Roma children and in Slovakia and Bulgaria at least 10\% attend segregated classes in mainstream schools. ${ }^{100}$

Moreover, education systems face numerous challenges in providing equity to refugee children, who are five times more likely to be absent from school than non-refugee children. ${ }^{101}$ For example, the 2016 report showed that $61 \%$ of refugee children attend primary school, compared to $92 \%$ globally. ${ }^{102}$ Refugee children tend to drop out of school twice as often as local children ( $25.4 \%$ vs. $11.5 \%)$, and this is mostly due to socioeconomic reasons. ${ }^{103}$ The number of refugee children in Croatia is rather low, with only 43 children enrolled in primary school and 7 in secondary school in 2017. ${ }^{104}$ Compared to local children, their share among children attending school is around $1 \% .^{105}$

96 Ćwirynkało, K. et. al. Attitudes of Croatian and Polish Elementary School Teachers Towards Inclusive Education of Children with Disabilities, Hrvatska revija za rehabilitacijska istraživanja, Vol. 53, 2018, p. 254.

${ }_{97}$ In Europe, the number of Roma children ranges between 10 and 12 million. Global education monitoring report, 2020, op. cit., note 87, p. 74 .

98 In the national minority, the number of Roma children attending compulsory primary school is as high as in the general population, at $95 \%$, but the enrolment rate drops significantly at secondary level, at only 35\%. Global Education Monitoring Report: Croatia, United Nations Educational, Scientific and Cultural Organization, 2021, p. 28, [https://gem-report-2020.unesco.org/wp-content/uploads/2021/02/ Croatia.pdf], Accessed 01 April 2021.

99 Global education monitoring report, 2020, op. cit., note 87, p. 71.

100 Ibid.

101 Global Education Monitoring Report/UNESCO, 2016, Global Education Monitoring Report 2016: Education for people and planet, Enforcing the right to education of refugees, p. 4, [https://en.unesco.org/ gem-report/taxonomy/term/198], Accessed 01 April 2021.

102 Ibid., p. 5.

103 In $2017,61 \%$ of refugee children attended primary school, compared to $92 \%$ globally. Enforcing the right to education of refugees. Ibid., p. 5.

104 Croatia: Education for better immigrant integration, [https://www.cedefop.europa.eu/en/news-andpress/news/croatia-education-better-immigrant-integration], Accessed 25 March 2021.

Ibid. 
Therefore, in addition to providing educational services to children, schools need to focus not only on academic achievement, but also on their health and social, emotional, mental and physical well-being in order to ensure an education that is inclusive and accessible, especially for vulnerable or disadvantaged groups. ${ }^{106}$ However, the COVID-19 pandemic and with it connected school closings have a significant negative impact on academic performance and socio-emotional learning. ${ }^{107}$ To reduce the loss of face-to-face teaching, schools have sought to rapidly disseminate education online and other distance learning resources, including teaching on the Internet, television and radio, and printed learning materials. These efforts have produced results that the content and quality of distance learning vary widely. ${ }^{108}$ Children's ability to participate in learning is highly dependent on the resources and support available in each home. ${ }^{109}$ Barriers to information and communication technology, infrastructure and digital literacy make it difficult for students to access distance learning options. ${ }^{110}$

Thus, the COVID -19 pandemic and with it related online education exacerbated the problem of equal access to education, as the shift to distance learning and the loss of instructional time exacerbated existing inequalities. ${ }^{111}$ The physical closure of schools and the shift to distance learning increased the challenges for children in terms of needing good digital skills, access to technology or the internet and support for learning at home. ${ }^{12}$ As technology was only an important part of the educational experience for a proportion of children, usually in secondary school, many children were denied access to education during the COVID -19 pandemic. ${ }^{113}$

106 UNESCO, International Commission on the Futures of Education, "Education in a post COVID-19 world: Nine ideas for action”, 2020, pp. 7, 9, [https://unesdoc.unesco.org/ark:/48223/pf0000373717/ PDF/373717eng.pdf.multi], Accessed 29 April 2021.

107 Ibid, p. 7.

108 Ibid.

109 Ibid.

110 Ibid.

111 Equity in school education in Europe Structures, policies and student performance, Eurydice report, Luxembourg: Publications Office of the European Union, 2020, p. 13, [https://eacea.ec.europa.eu/national-policies/eurydice/sites/eurydice/files/equity_2020_0.pdf], Accessed 01 April 2021.

112 Ibid.

113 In Germany, for example, at most 1 in 4 8th grade students reported using information and communication technology weekly to work online with other students or to write and edit documents. Global Education Monitoring Report/UNESCO, 2016, Global Education Monitoring Report 2016: Education for people and planet, Enforcing the right to education of refugees, p. 59, [https://en.unesco.org/gem-report/ taxonomy/term/198], Accessed 01 April 2021. 
Children with disabilities (e.g. blind or deaf children) are at higher risk of exclusion in such circumstances, as many educational resources are still inaccessible to them, even when the technology is available. Children with mild learning disabilities (e.g. attention deficit hyperactivity disorder), on the other hand, find it difficult to work independently in front of a computer. ${ }^{114}$ Children who are ethnic minorities, refugees, or live in low-income families face socioeconomic barriers to accessing resources for online learning because they do not have internet access, a quiet place to study during a closure, or reading materials. ${ }^{115}$ All of the above issues have a negative impact on ensuring the adequacy and equitable access to quality distance learning opportunities guaranteed to children by the right to education. ${ }^{116}$

Regardless, all children should receive at least a minimum of a good education, and their achievement should be largely independent of natural gifts or socioeconomic background. In other words: if the state wants fair access to education, it must ensure that all children receive an appropriate level of education and equality.

The solution for this challenge could be found in Rawls' philosophical theory, which justifies giving priority to adequacy while maintaining the independent role of equality. ${ }^{117}$ Rawls' theory of justice is useful because it can be related to the adequacy of education under Rawls' first principle of justice and equality of opportunity for school success, which can be related to the first part of Rawls' second principle. ${ }^{118}$ Rawls' first principle is to guarantee equal fundamental rights and freedoms necessary to secure the basic interests of equal citizens and to pursue a broad range of conceptions of the good. ${ }^{119}$ When it comes to education, Rawls' first principle states that children have a right to an education that is adequate for them to attain equal citizenship and enjoy other rights and freedoms. Adequate

\footnotetext{
114 Global Education Monitoring Report/UNESCO, op. cit., note 101, p. 60.

115 Ibid.

116 Council conclusions on countering the COVID-19 crisis in education and Training, Council of the European Union, 2020, p. 4, [https://data.consilium.europa.eu/doc/document/ST-8610-2020-INIT/en/ pdf], Accessed 27 March 2021.

117 Ibid., p. 9.

118 Burroughs, op. cit., note 47, p. 2.

Rawls' two principles of justice are: "1. Each person has the same indefeasible claim to a fully adequate scheme of equal basic liberties, which scheme is compatible with the same scheme of liberties for all. 2. Social and economic inequalities are to satisfy two conditions: first, they are to be attached to offices and positions open to all under conditions of fair equality of opportunity and second, they are to be to the greatest benefit of the least advantaged members of society (the difference principle)". Rawls, J., Justice as Fairness: A Restatement, Cambridge, MA: Harvard University Press, 2001, p. 42.43.

Ibid.
} 
education, then, requires setting a threshold that enables the child to receive an education sufficient for the full development of his or her personality, talents, and mental and physical abilities. ${ }^{120}$ This means that the state should ensure that all children have equal access to education. It asks for support for the first part of Rawls' second principle, which states that places in schools should be open to all children, regardless of race, class or gender or socio-economic status. ${ }^{121}$ It prohibits the state from providing access to education on a discriminatory basis, as it must be open to all who can learn and meet the educational threshold. ${ }^{122}$ In the case of the COVID -19 pandemic, this would mean that the state should work to eliminate background disadvantages in the distribution of educational opportunities. ${ }^{123}$ Using Rawls' principle of fair equity of opportunity, children with equal natural talents and abilities and willingness to use them should have equal prospects of access to education regardless of race, class, gender, or socioeconomic status. ${ }^{124}$ The inequality of opportunities that can arise in access to education during the COVID-19 pandemic according to Rawls' principle of difference could only be justified if the state maximizes the well-being of the disadvantaged children. ${ }^{125} \mathrm{In}$ other words, any inequality in chances of access to education for children during the COVID-19 pandemic must be justified by the state with an increase in overall chances for those with fewer opportunities. ${ }^{126}$ For example, if child A and child B have the same talents, but $\mathrm{A}$ has a better chance of managing online school classes than $\mathrm{B}$ because of a favorable family situation, with the principle of fair equality of opportunity, the state should use resources so that B can run the online classes at the same level as A. ${ }^{127}$ In doing so, the state should reduce the arbitrariness of the natural lottery and maximizes the opportunities for the most disadvantaged children, defined as the opportunity to gain access to online education in the context of the COVID-19 pandemic. ${ }^{128}$ Therefore, all children should receive an adequate minimum level of education and the additional contribution of race,

\footnotetext{
120 Global annual results report 2019: Goal Area 2, UNICEF, 2019, [https://www.unicef.org/reports/global-annual-results-2019-goal-area-2], 27 March 2021.

121 Social and economic inequalities must satisfy two conditions: first, they must be associated with offices and positions open to all under conditions of fair equality of opportunity, and second, they must benefit the least advantaged members of society the most (the difference principle). Rawls, op. cit., note 118, pp. 42-43.

122 Satz, op. cit., note 52, p. 626.

123 Burroughs, op. cit., note 47, p. 2.

124 Rawls, op. cit., note 118, p. 73.

125 Alexander, L., A., Fair Equality of Opportunity: John Rawl' (Best) Forgotten Principle, Philosophy Research Archives, Vol. 11, 1985, p. 199.

126 Ibid., p. 200.

127 Ibid., p. 202.

128 Ibid., p. 203., Rawls, op. cit., note 118, p. 74.
} 
class, or gender, or socio-economic status is not significant. Such online education should be: (a) available via application using trained teachers, classroom materials, computer facilities and information technology; (b) economically accessible; (c) acceptable in terms of curriculum and teaching methods; and (d) adaptable or "flexible" to the needs of changing societies and communities and to meet the needs of students in their diverse social and cultural environments. ${ }^{129}$

To achieve this goal, the state should take practical measures to provide online education to all children during the COVID-19 pandemic. This means that state needs to conduct research to identify appropriate distance learning options to establish minimum standards for online learning. ${ }^{130}$ In addition, the state should ensure that new and existing online platforms are user-friendly and accessible to children with different disabilities, and the state should also invest in and develop online learning, including investing in technological equipment and developing online platforms and materials. ${ }^{31}$ Children of different ages and levels of education also learn differently in distance learning which interferes with equal access to education. Younger children need more parent/teacher support for learning and do not have the same ability to learn and self-regulate for independent learning as older children. ${ }^{132}$ Therefore, it is important that the state provides ongoing training and develop the skills of teachers, parents, and caregivers to support children's home learning and socio-emotional needs. ${ }^{133}$

\section{CONCLUSION}

Education is of particular importance to children because with a quality education, they are more likely to succeed in life and achieve better life goals than children who do not have a quality education. It gives children the opportunity to pursue their dreams, interests, and passions and makes all human intellectual accomplishments available. Due to differences in learning abilities caused by innate talents, influences and conditions outside of school, children around the world have unequal opportunities to access education. These inequalities deepened with

129 Right to education: impact of the COVID-19 crisis on the right to education: concerns, challenges and opportunities, Report of the Special Rapporteur on the right to education, Article 14, para 1, 2020, [https:// www.ohchr.org/EN/Issues/Education/SREducation/Pages/COVID19.aspx], Accessed 01 April 2021.

131 Ibid.

132 Andaleeb, A.; Priyamvada T., Putting the "learning" back in remote learning, Policies to uphold effective continuity of learning through COVID-19, UNICEF, 2020, p. 4, 7, [https://www.unicef.org/globalinsight/sites/unicef.org.globalinsight/files/2020-06/UNICEF-Global-Insight-remote-learning-issuebrief-2020.pdf], Accessed 30 April 2021.

Ibid. 
the COVID-19 pandemic and the closure of educational institutions as many disadvantaged children lost access to education. At that time, states had failed to maintain the minimum level of education for all children as a basis for adequate education. To maintain the minimum level of education in a pandemic, the state must create policies that enable positive educational outcomes that are attainable for all children. Policies should be developed in line with Rawlsian theory of justice, which advocates for fair equality of opportunity that aims not only at adequate access to education but also at equal participation in it. This means that personal and social circumstances should not be a barrier to access to education and that every child has the right to the necessary educational resources to achieve an adequate level of education. To achieve this, the state must ensure that measures are available, accessible, acceptable and adaptable to remove barriers to education and target disadvantaged and vulnerable children to ensure their access to education.

For example, the state must ensure the availability of digital and other distance learning materials created to support the learning continuum; time-limited free internet data packages at zero cost for educational content or other measures, food vouchers, meal deliveries, take-home rations, cash transfers or other means, and so on. ${ }^{134}$ In enacting these measures, the state should bear in mind that the right to education is particularly important for children and that any restriction on children's rights can be justified if it is in the best interests of children, especially the most vulnerable children, which is consistent with the second part of Rawls' second principle, which allows for inequalities only when they are for the greatest benefit of children. ${ }^{135}$

Although the measures aim to provide children with access to education and the right to education by protecting children's interests during a pandemic, they should only be a temporary solution because education, in addition to imparting knowledge, also aims to develop socio-emotional skills that require real human interactions between children and teachers and pears that can never be replaced by online schools. ${ }^{136}$

134 Building back equal: girls back to school guide, The Malala Fund, Plan International, UNESCO, UNGEI and UNICEF, 2020, pp. 8.,10, [https://www.unicef.org/reports/building-back-equal-girls-backto-school-guide-2020], Accessed 01 April 2020.

135 "... second, they are to be to the greatest benefit of the least advantaged members of society (the difference principle)". Rawls, op. cit., note 118, p. 42-43.

136 Burroughs, op. cit., note 47, p. 2.

Right to education: impact of the COVID-19 crisis on the right to education; concerns, challenges and opportunities, op. cit., note 118, Article 47. 


\section{REFERENCES}

\section{BOOKS AND ARTICLES}

1. Alexander, L., A., Fair Equality of Opportunity: John Rawls' (Best) Forgotten Principle, Philosophy Research Archives, Vol. 11, 1985, pp. 197-208

2. Beiter, K., D., The Protection of the Right to education The Protection of the Right to Education by International Law: Including a Systematic Analysis of Article 13 of the International Covenant on Economic, Social and Cultural Rights, Martinus Nijhoff, International Studies in Human Rights, Vol. 82, 2006

3. Burroughs, N. A., Rawls, republicanism, and the adequacy-equity debate, Theory and Research in Education, Vol. 14, Issue 2, 2016, p. 226-240

4. Ćwirynkało, K. et. al. Attitudes of Croatian and Polish Elementary School Teachers Towards Inclusive Education of Children with Disabilities, Hrvatska revija za rehabilitacijska istraživanja, Vol. 53, 2018, p. 252-264

5. Giesinger, J., Educational justice: equality versus adequacy, in: Peters, Michael A.(ed.), Encyclopedia of educational philosophy and theory, Cham, Switzerland: Springer Singapore, 2018, pp. 1-10

6. Heymann, J., et. al., Constitutional rights to education and their relationship to national policy and school enrolment, International Journal of Educational Development, Vol. 39, 2014, p. 131-141

7. Hodgson, D., The international human right to education and education concerning human rights, International Journal of Children's Rights, Vol. 4, No. 3, 1996, pp. 237-262

8. Hohfeld, W., Fundamental Legal Conceptions, New Haven: Yale University Press, 1919

9. Menéndez, F. S., Educational adequacy and educational equality: a merging proposal, Critical Review of International Social and Political Philosophy, Vol. 22, Issue 1, 2019, p. 1-22

10. Parks, A., Children and International Human Rights Law: The Right of the Child to be Heard, Routledge, 2013

11. Pimentel, C., The Human Right to Education: Freedom and Empowerment, Multicultural Education, Vol. 13, No. 4, 2006, p. 2-10

12. Podschwadek, F., Rawlsian liberalism and public education, $\mathrm{PhD}$ thesis, University of Glasgow, 2018

13. Rawls, J., Justice as Fairness: A Restatement, Cambridge, MA: Harvard University Press, 2001

14. Satz, D., Equality, Adequacy, and Education for Citizenship, Symphosium on Education and Equality, Ethics, Vol. 117, No. 14, 2007, pp. 623-648

15. Weishart, J. E., Reconstituting the right to education, Alabama Law Review, Vol. 67, No. 4, 2016, p. $917-978$

\section{ECHR}

1. Case Relating to Certain Aspects of the Laws on the Use of Languages in Education in Belgium, European Commission of Human Rights v Belgium, Merits, App No 1474/62, App 
No 1677/62, App No 1691/62, App No 1769/63, App No 1994/63, App No 2126/64, (1979-80) 1 EHRR 252, IHRL 6 (ECHR 1968), 23rd July 1968

2. Golder v United Kingdom, Judgment, Merits and Just Satisfaction, App No 4451/70, A/18, [1975] ECHR 1, (1979) 1 EHRR 524, IHRL 9 (ECHR 1975), 21st February 1975

3. Şahin v Turkey, Admissibility and Merits, App No 44774/98, ECHR 2005-XI, [2005] ECHR 819, (2007) 44 EHRR 5, (2006) 45 ILM 436, [2006] ELR 73, 19 BHRC 590, IHRL 3279 (ECHR 2005), 10th November 2005

4. Folgerø and ors v Norway, Merits and just satisfaction, App no 15472/02, (2008) 46 EHRR 47, IHRL 3235 (ECHR 2007), 29th June 2007

5. Campbell and Cosans v United Kingdom, Merits, App No 7511/76, A/48, [1982] ECHR 1, (1982) 4 EHRR 293, IHRL 33 (ECHR 1982), 25th February 1982

6. Tarantino and ors v Italy, Merits and just satisfaction, App nos 25851/09, IHRL 3986 (ECHR 2013), 29284/09, 64090/09, [2013] ECHR 255, 9th September 2013

7. Oršuš and ors v Croatia, Merits and just satisfaction, App no 15766/03, IHRL 3716 (ECHR 2010), 16th March 2010

\section{INTERNATIONAL LAW}

1. UN General Assembly, Universal Declaration of Human Rights, 10 December 1948, 217 A (III), [https://www.refworld.org/docid/3ae6b3712c.html], Accessed 03 March 2021

2. UN General Assembly, Declaration of the Rights of the Child, 20 November 1959, A/ RES/1386(XIV), [https://www.refworld.org/docid/3ae6b38e3.html], Accessed 03 March 2021

3. UN Educational, Scientific and Cultural Organisation (UNESCO), Convention Against Discrimination in Education, 14 December 1960, [https:/www.refworld.org/ docid/3ae6b3880.html], Accessed 04 March 2021

4. UN General Assembly, International Covenant on Economic, Social and Cultural Rights, 16 December 1966, United Nations, Treaty Series, vol. 993, p. 3, [https://www.refworld. org/docid/3ae6b36c0.html], Accessed 03 March 2021

5. UN General Assembly, Convention on the Rights of the Child, 20 November 1989, United Nations, Treaty Series, vol. 1577, p. 3, [https://www.refworld.org/docid/3ae6b38f0.html], Accessed 03 March 2021

6. UN Committee on the Rights of the Child (CRC), General comment No. 1 (2001), Article 29 (1), The aims of education, 17 April 2001, CRC/GC/2001/1, paragraph 2., p. 2., [https://www.refworld.org/docid/4538834d2.html], Accessed 05 March 2021

\section{EU LAW}

1. Regulation (EEC) No 1612/68 of the Council of 15 October 1968 on freedom of movement for workers within the Community OJ L 257, 19.10.1968

2. Council Directive 77/486/EEC of 25 July 1977 on the Education of the Children of Migrant Workers OJ L 199, 6.8.1977 
3. Resolution adopting the Declaration of Fundamental Rights and Freedoms A2-3/89, OJ C 120 of 16.05 .1989

4. Treaty establishing the European Community (Consolidated version 2002) OJ C 325, 24.12.2002

5. Charter of Fundamental Rights of the European Union OJ C 326, 26.10.2012

\section{COUNCIL OF EUROPE DOCUMENTS}

1. Council of Europe, Protocol 1 to the European Convention for the Protection of Human Rights and Fundamental Freedoms, 20 March 1952, ETS 9, available at: [https://www. refworld.org/docid/3ae6b38317.html] Accessed 28 April 2021

2. Council of Europe, European Convention on the Legal Status of Migrant Workers, 24 November 1977, ETS 93, [https://www.refworld.org/docid/3ae6b388c.html], Accessed 19 March 2021

3. Council of Europe, European Charter for Regional or Minority Languages, 4 November 1992, ETS 148, available at: [https://www.refworld.org/docid/3de78bc34.html], Accessed 7 April 2021

4. Council of Europe, Framework Convention for the Protection of National Minorities, 1 February 1995, ETS 157, [https://www.refworld.org/docid/3ae6b36210.html], Accessed 07 April 2021

5. Council of Europe, European Social Charter (Revised), 3 May 1996, ETS 163, [https:// www.refworld.org/docid/3ae6b3678.html], Accessed 05 March 2021

6. Council of Europe: Recommendation CM/Rec(2009) 4 of the Committee of Ministers to member states on the education of Roma and Travellers in Europe, 17 June 2009

7. Council of Europe: Committee of Ministers, Recommendation No. R (2000) 4 of the Committee of Ministers to member states on the education of Roma/Gypsy children in Europe, 3 February 2000, R (2000) 4, available at: [https://www.refworld.org/docid/469e04c02. html], Accessed 08 April 2021

8. Council of Europe: Recommendation CM/Rec(2012)13 of the Committee of Ministers to member States on ensuring quality education, 12 December 2012

9. Council of Europe: Committee of Ministers, Recommendation CM/Rec(2012)7 of the Committee of Ministers to member States on the responsibility of public authorities for academic freedom and institutional autonomy, 20 June 2012, [https://www.refworld.org/ docid/50697ed62.html], Accessed 08 April 2021

\section{LIST OF NATIONAL REGULATIONS, ACTS AND COURT DECISIONS}

1. The Constitution of the Republic of Croatia, Official Gazette No. 56/90, 135/97, 08/98, 113/00, 124/00, 28/01, 41/01, 55/01, 76/10, 85/10, 05/14

2. The Constitutional Act on the Rights of National Minorities, Official Gazette, No. 155/02, 47/10, 80/10, 93/11

3. Act on the Use of Languages and Scripts of National Minorities in the Republic of Croatia, Official Gazette, No. 51/00 
4. Act on the Use of Languages and Scripts of National Minorities in the Republic of Croatia, Official Gazette, No. 51/00

5. Act on Scientific Activity and Higher Education, Official Gazette, No. 123/03, 198/03, 105/04, 174/04, 02/07, 46/07, 45/09, 63/11, 94/13, 139/13, 101/14 and 60/15

6. Act on Scientific Activity and Higher Education, Official Gazette, No. 123/03, 198/03, 105/04, 174/04, 02/07, 46/07, 45/09, 63/11, 94/13, 139/13, 101/14 and 60/15

7. Law on International and Temporary Protection, Official Gazette, No. 70/15, 127/17

8. Primary and Secondary School Education Act, Official Gazette, No. 87/08, 86/09, 92/10, $105 / 10,90 / 11,5 / 12,16 / 12,86 / 12,126 / 12,94 / 16,154 / 14,7 / 17$

\section{WEBSITE REFERENCES}

1. [http://uis.unesco.org/en/glossary-term/basic-education], Accessed 22 March 2021

2. [https://www.iea.nl/studies/iea/pirls/2016], Accessed 31 March 2021

3. [https://www.unicef.org/press-releases/schools-more-168-million-children-globally-havebeen-completely-closed], Accessed 31 March 2021

4. Andaleeb, A.; Priyamvada T., Putting the "learning" back in remote learning, Policies to uphold effective continuity of learning through COVID-19, UNICEF, 2020, [https:/www. unicef.org/globalinsight/sites/unicef.org.globalinsight/files/2020-06/UNICEF-Global-Insight-remote-learning-issue-brief-2020.pdf], Accessed 30 April 2021

5. Blaskó, Z.; Schnepf, S., V., Educational inequalities and physical school closures during Covid-19, 2020, [https://ec.europa.eu/jrc/en/research/crosscutting-activities/fairness], Accessed 31 March 2021

6. Building back equal: girls back to school guide, The Malala Fund, Plan International, UNESCO, UNGEI and UNICEF, 2020, pp. 8.,10, [https://www.unicef.org/reports/buildingback-equal-girls-back-to-school-guide-2020], Accessed 01 April 2020

7. Council conclusions on countering the COVID-19 crisis in education and Training, Council of the European Union, 2020, p. 4, [https://data.consilium.europa.eu/doc/document/ST8610-2020-INIT/en/pdf], Accessed 27 March 2021

8. Croatia: Education for better immigrant integration, [https:/www.cedefop.europa.eu/en/ news-and-press/news/croatia-education-better-immigrant-integration], Accessed $25 \mathrm{March}$ 2021

9. Early leavers from education and training, p. 77, [https://ec.europa.eu/eurostat/statistics-explained/index.php/Early_leavers_from_education_and_training], Accessed 23 March 2021

10. Education, [https://eige.europa.eu/gender-mainstreaming/policy-areas/education], Accessed 23 March 2021

11. Enforcing right to education of refugees: a policy protection, United Nations Educational, Scientific and Cultural, 2019, p. 26, [https://www.gcedclearinghouse.org/sites/default/files/ resources/190208eng.pdf], Accessed 07 April 2021

12. Equal access to education, [https://europa.eu/capacity4dev/public-gender/wiki/equal-accesseducation], Accessed 01 April 2021 
13. Equity in school education in Europe Structures, policies and student performance, Eurydice report, Luxembourg: Publications Office of the European Union, 2020, p. 13, [https://eacea. ec.europa.eu/national-policies/eurydice/sites/eurydice/files/equity_2020_0.pdf], Accessed 01 April 2021

14. European Framework, [https://www.right-to-education.org/page/european-framework], Accessed 19 March 2021

15. Gender and Education (and Employment) Gendered imperatives and their implications for women and men lessons from research for policy makers, European Commission, 2003, p. 78, [http://www.nesse.fr/nesse/activities/reports/activities/reports/gender-report-pdf], Accessed 23 March 2021

16. Gender Differences in Educational Outcomes: Study on the Measures Taken and the Current Situation in Europe, Education, Audiovisual and Culture Executive Agency, 2010, p. 47, [http://lst-iiep.iiep-unesco.org/cgi-bin/wwwi32.exe/[in=epidoc1.in]/?t2000=028612/ (100)], Accessed 23 March 2021

17. Global annual results report 2019: Goal Area 2, UNICEF, 2019, [https://www.unicef.org/ reports/global-annual-results-2019-goal-area-2], Accessed 27 March 2021

18. Global education monitoring report, 2020: Inclusion and education: all means all, Educational, Scientific and Cultural Organization, 2020, p. 67, [https://unesdoc.unesco.org/ark:/48223/ pf0000373718], Accessed 01 April 2021

19. Global Education Monitoring Report/UNESCO, 2016, Global Education Monitoring Report 2016: Education for people and planet, Enforcing the right to education of refugees, p. 4., [https://en.unesco.org/gem-report/taxonomy/term/198], Accessed 01 April 2021

20. Global Education Monitoring Report: Croatia, United Nations Educational, Scientific and Cultural Organization, 2021, p. 28, [https://gem-report-2020.unesco.org/wp-content/uploads/2021/02/Croatia.pdf], Accessed 01 April 2021

21. Is education compulsory?, [https://www.worldpolicycenter.org/policies/is-education-compulsory/is-primary-education-compulsory], Accessed 01 April 2021

22. Is education tuition-free and compulsory?, [https://www.worldpolicycenter.org/policies/is-education-tuition-free-and-compulsory/is-primary-education-tuition-free-and-compulsory], Accessed 01 April 2021

23. Lynch, K.; Feeley, M., Gender and Education (and Employment) Gendered imperatives and their implications for women and men lessons from research for policy makers, European Commission, 2003, p. 78, [http://www.nesse.fr/nesse/activities/reports/activities/reports/genderreport-pdf], Accessed 23 March 2021

24. Minorities in Croatia, 2003, p. 25, [https://www.refworld.org/pdfid/469cbf8f0.pdf], Accessed 24 March 2021

25. Organisation of the Education System and of its Structure, [https://eacea.ec.europa.eu/national-policies/eurydice/content/organisation-education-system-and-its-structure-14_en], Accessed 24 March 2021

26. PISA 2015 Programme for International Student Assessment - Europe and Central Asia, World Bank Group Education, 2015, p. 7, [http://documents1.worldbank.org/curated/ en/674021500448761959/pdf/117585-PIS A-2015-ECA.pdf], Accessed 23 March 2021 
27. Report on the Protection of Children's Rights, Council of Europe, adopted by the Venice Commission at its 98th Plenary Session, Venice, 21-22 March 2014, p. 19, [https://rm.coe. int/168062cf94], Accessed 01 April 2021

28. Right to Education, [https://www.right-to-education.org/page/international-law], Accessed 01 April 2021

29. Right to education: impact of the COVID-19 crisis on the right to education: concerns, challenges and opportunities, Report of the Special Rapporteur on the right to education, Article 14, para 1, 2020, [https://www.ohchr.org/EN/Issues/Education/SREducation/Pages/COVID19.aspx], Accessed 01 April 2021

30. Steering Committee for Equality Between Women and Men (CDEG), Strasbourg, 2011, p. 24. [https://rm.coe.int/1680596131], Accessed 01 April 2021

31. UNESCO, International Commission on the Futures of Education, "Education in a post COVID-19 world: Nine ideas for action”, 2020, [https://unesdoc.unesco.org/ark:/48223/ pf0000373717/PDF/373717eng.pdf.multi], Accessed 29 April 2021

32. Wilson, D., Gender equality in education: Human right perspective, p. 11, [https://www. ohchr.org/Documents/HRBodies/CEDAW/WomensRightEducation/DuncanWilson. pdf], Accessed 01 April 2021

33. Women and the right to education, United Nations Human Rights Office of the High Commissioner, 2010, [https://www.ohchr.org/Documents/Issues/Women/GenderAndEquality/ Infonote_Women_and_the_right_to_education.pdf], Accessed 23 March 2021

34. World report on disability, World Health Organisation, 2011, p. 206, [https://www.right-toeducation.org/sites/right-to-education.org/files/resource-attachments/WHO_World_Report_on_Disability_2011_En.pdf], Accessed 31 March 2021 